\title{
The Marie Tremaine Medal
}

\section{La Médaille Marie Tremaine}

The Marie Tremaine Medal is awarded annually by the Bibliographical Society of Canada / La Société bibliographique du Canada for outstanding service to Canadian bibliography and for distinguished publication in either English or French in that field, preferably to a member of the Society or to a Canadian citizen. Members of the Council of the Society are not eligible for the award while they are in office. The Tremaine Medal Committee invites nominations for this award.

Previous recipients of the Tremaine Medal have been Marie Tremaine, 1970; John Hare and Jean-Pierre Wallot, 1973; Bruce Braden Peel, 1975; William F.E. Morley, 1977; Reginald Eyre Watters, 1979; Olga Bernice Bishop, 198I; Alan F.J. Artibise, 1983; Douglas Grant Lochhead, I985; Agnes Celia O'Dea, 1987; Sandra Alston, 1988; Gloria M. Strathern, I989; Claude Galarneau, I990; Patricia Fleming, I992; Joan Winearls, I993; and Paul Aubin, I994.

La Société bibliographique du Canada / Bibliographical Society of Canada attribue la Médaille Marie Tremaine tous les ans pour services exceptionnels rendus à la cause de la bibliographie canadienne et pour des publications de haute qualité dans ce domaine, soit en français, soit en anglais, préférence étant accordée aux membres de la Société et aux citoyens canadiens. Les membres du Conseil de la Société ne sont pas admissibles pendant les années de leur mandat. La Comité de sélection de la Médaille Marie Tremaine sollicite des candidatures pour le concours.

La Médaille Tremaine a précédemment été décernée à Marie Tremaine, I970; John Hare et Jean-Pierre Wallot, 1973; Bruce Braden Peel, 1975; William F.E. Morley, I977; Reginald Eyre Watters, 1979; Olga Bernice Bishop, I98I; Alan F.J. Artibise, 1983; Douglas Grant Lochhead, 1985; Agnes Cecilia O'Dea, 1987; Sandra Alston, I988; Gloria M. Strathern, 1989; Claude Galarneau, I990; Patricia Fleming, 1992; Joan Winearls, 1993; et Paul Aubin, I994. 


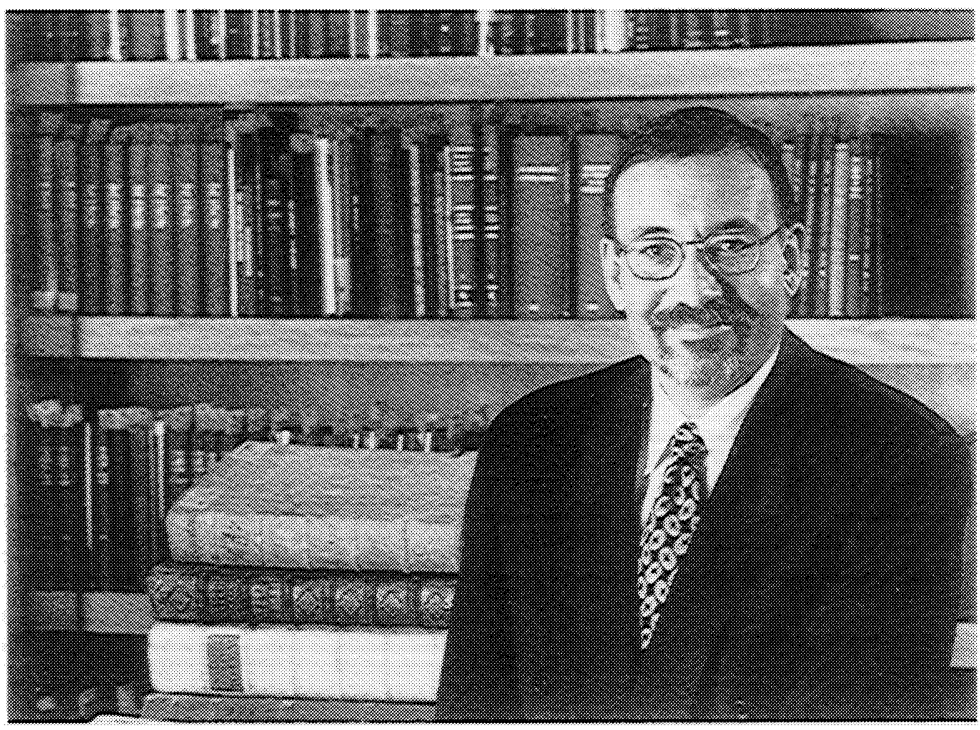

At the Annual Meeting of the Bibliographical Society of Canada on IO-I I June I996 in Halifax, the following citation was read by Thomas B. Vincent, the President of the Society:

The Council of the Bibliographical Society of Canada, on the unanimous recommendation of its Tremaine Medal Committee, is very pleased to award the I996 Tremaine Medal in Canadian Bibliography to Mr. Ernie Ingles 'for outstanding service to Canadian bibliography and for distinguished publication in that field.'

Ernest Boyce Ingles, better known to his friends and to the world at large as 'Ernie,' has been an active member of the Bibliographical Society of Canada for many years, and is in fact one of its past Presidents.

Ernie, who is currently the Chief Librarian and Director of Informations Systems at the University of Alberta, began his academic career as the rare book librarian at the University of Calgary. At Calgary with the late Ken Glazier, he established the Canadian 
Writers' Movement Collection. He then embarked upon the first of his major contributions to Canadian bibliography and scholarly activity, as the founding Director of the Canadian Institute for Historical Microreproductions - now commonly known as CIHM. In that capacity, he oversaw the preservation on microfiche of Canada's published literary heritage to 1900 . Often faced with incomplete and inadequate bibliographies and reference sources, the work of Ernie and his staff at Сाнм in large measure involved defining with greater bibliographical precision the printed heritage of Canada before the twentieth century. One cannot give enough importance to the success of this project since the greatest difficulty in the field of research related to Canadian studies in general and of Canadian bibliography in particular has always been the problem of access to published texts.

In addition to his work at CIHM, Ernie's bibliographical achievements include three substantial bibliographies which have become indispensable reference guides for virtually all topics relating to Canada and Canadian studies. His most recent bibliography, the third edition of Bibliography of Canadian Bibliographies (r 994), is a monumental work, which was sponsored by the Society and undertaken with the financial support of the Social Sciences and Humanities Research Council of Canada.

It is therefore with great pleasure that I ask our friend and colleague, Ernie Ingles, to come forward and to receive the Marie Tremaine Medal of the Bibliographical Society of Canada. I know that I speak for all of you in expressing our collective affection and congratulations.

The following response was made by Ernie Ingles:

Ladies and gentlemen, it is a great pleasure for me to be here tonight on the occasion of the fiftieth anniversary of the Bibliographical Society of Canada to accept this magnificent award. You cannot really know how happy and proud I am to have been nominated and to have been chosen as the recipient of the Marie Tremaine Medal. I am particularly touched by this honour. My name will be added to the list of former winners of the Medal, many of whom have inspired me greatly and over the years have been my guides and friends. This recognition is very precious to me.

'Recognition' is one of those rich and multi-faceted words. It connotes a lexical mountain of positive images - images such as 
accomplishment, service, merit, and consideration to name but a few. The word springs from honourable etymological roots. Indeed, its linguistic lineage is most a propos of bibliography; that is, 'recognition' from the Latin 'recognitio,' meaning the recovery of knowledge. When modified in the appropriate manner the word can take on an even greater meaning. Consider the phrase 'peer recognition.' Modified in such a manner the resulting phrase means something quite different and quite exceptional. I am greatly honoured in this expression of your recognition.

But, recognition is two-way. For my part, the recognition which I enjoy tonight must be shared. My bibliographical accomplishments - perhaps better characterized as bibliographical adventures have been the product of collaborations. For example, when I was at the University of Calgary I enjoyed the colleagueship of Apollonia Steele who is here tonight. The work of the Canadian Institute for Historical Microreproductions (СIHM) was a bibliographical 'high' for me, not only in so far as the contribution I was able to make to Canadian scholarship, but in so doing I was working with such previous Tremaine winners as Doug Lochhead and Bruce Peel both of whom I thank as friends and mentors. Others such as Basil Stuart-Stubbs and the late David Esplin also demand my recognition and thanks. And there were, of course, my work colleagues such as my successor Bob Montaque. More recently my 'adventures' involved the compilation of the Bibliography of Canadian Bibliog. raphy $(B C B: 3)$. Here I owe thanks to my co-researcher Gordon Adshead, as well as to other associates such as Donna BrockmeyerKlebaum who is also here this evening. In addition, I would thank friend and colleague Merrill Distad.

In addition to these individuals, a particular debt of gratitude is owed to the staff of the National Library of Canada. Whether with regard to the work of CIHM or the preparation of the $B C B: 3$, the support of National Librarians' Guy Sylvestre and Marianne Scott, as well as the staff of NL, has been invaluable. Marianne ... I would ask that you take this sentiment back to your staff.

And finally, I would thank all previous individuals who have laboured in the bibliographical arts and without whose labours my work would either have been much, much more difficult or would not have been possible at all. $B C B: 3$ is a testament to their contributions.

Permit me to close with a short anecdote. Today we are buffeted on all sides by discussions as to the demise of the book, as well as the general reductions in funding for research, collection building and so forth. In this environment it is easy to be discouraged. When 
I think in such terms I am reminded of my great grandfather. In his early teens he crossed an ocean, and worked his way from New York to northern Manitoba where he established a homestead. Here, still in his mid-teens he cleared his land by hand, increasingly tilled a larger and larger acreage, and with my great grandmother raised a family of three. In so doing, with others in like circumstances, he created the inheritance which is ours today. He did this, as did many of his generation, without the benefit of an education - yet they were learned. We have much to be thankful for as we recognize our mutual accomplishments - and worry about our circumstances. Our challenge is to work with those resources which are ours to command, and remember those who accomplished as much, if not more, with significantly less. Let us recognize their achievement for they built a nation. 
I 996: LA MÉDAILLE TREMAINE DÉCERNÉE À ERNIE INGLES:

À la conférence de la Société bibliographique du Canada tenue à Halifax, le IO-I I juin I996, la citation suivante a été lue par Thomas B. Vincent, Président de la Société:

Suite à la recommandation unanime du Comité de la Médaille Tremaine, le Conseil de la Société bibliographique du Canada est très heureux de décerner la Médaille Tremaine de Bibliographie canadienne pour I 996 à Monsieur Ernie Ingles «pour souligner l'excellence des services rendus à la bibliographie canadienne et la qualité exceptionelle des publications dans ce domaine."

Ernest Boyce Ingles; mieux connu de ses amis et du monde en général sous le nom de “Ernie," a été un membre actif de la Société depuis de nombreuses années et fut même un de ses anciens présidents.

Ernie, qui est présentement bibliothécaire-en-chef et directeurgénéral des systèmes de l'information à l'Université de l'Alberta, débuta sa carrière comme bibliothécaire des livres rares à l'université de Calgary. À Calgary, en compagnie du regretté Ken Glazier, il entreprit de mettre sur pied la Collection des manuscrits des écrivains canadiens. C'est comme directeur-fondateur de l'Institut canadien de microreproductions historiques, maintenant mieux connu sous le nom de IсмH, qu'il fit la premiére de ses nombreuses contributions à la bibliographie canadienne et à la recherche académique. C'est dans ce rôle qu'il dirigea le projet de conservation sur microfiche de l'héritage littéraire canadien imprimé avant 1900. Souvent confronté à des bibliographies incomplètes et indéquates, Ernie et son équipe de ICMH réussirent à définir avec une plus grande précision bibliographique l'héritage imprimé canadien avant le vingtième siècle. On ne pourra jamais donner assez $\mathrm{d}$ 'importance à cette réussite puisque la plus grande difficulté dans le domaine de la recherche en études canadiennes en général et de la bibliographie canadienne en particulier a toujours été l'accès aux textes publiés.

En plus de son travail à ICMH, les réussites bibliographiques $\mathrm{d}^{\prime}$ Ernie incluent trois bibliographies qui sont devenues des ouvrages de référence et des guides indispensables à l'étude de tous les sujets relatifs au Canada et aux études canadiennes. La plus récente de ces bibliographies, la troisième édition de Bibliographie des bibliographies canadiennes, est un ouvrage monumental qui fut entrepris 
avec le soutien financier du Conseil de recherches en sciences humaines du Canada et la bénédiction de notre Société.

$C^{\prime}$ 'est donc avec grand plaisir que j'invite notre ami et collègue, Ernie Ingles, à s'approcher de la tribune pour recevoir la médaille Marie Tremaine de la Société bibliographique du Canada. Je suis certain que je parle au nom de tous et toutes en lui exprimant notre affection et nos félicitations.

\section{Ernie Ingles a répondu de la façon suivante:}

Mesdames et messieurs, c'est un grand plaisir pour moi d'être ici ce soir, à l'occasion de ce cinquantième anniversaire, pour accepter ce magnifique prix. Les membres de la Société ne savent pas jusqu'à quel point je suis heureux et fier d'avoir été proposé et choisi comme récipiendaire de la médaille Tremaine. Je suis particulièrement touché de cet honneur. Il vient ajouter mon nom à une liste $\mathrm{d}^{\prime}$ anciens récipiendaires qui m'inspirent beaucoup d'admiration et dont plusieurs ont été, au cours des années, mes guides et mes amis. Cette reconnaissance $m^{\prime}$ est très précieuse.

Le terme "reconnaissance» est un de ces mots riche en nombreuses significations. Il fait surgir une foule d'images positives des images telles que réussite, service, mérite et considération pour n'en nommer que quelques-unes. Le mot provient de racines étymologiques honorables. En effet, sa lignée linguistique s'applique très bien à la bibliographie; c'est-à-dire "reconnaissance» du latin "recognitio" qui veut dire la récupération du savoir. Lorsque modifié d'une façon appropriée le terme peut prendre une signification encore plus étendue. Prenez par exemple la phrase creconnaissance de ses pairs». Modifiée de cette façon, la phrase qui en résulte signifie quelque chose de très différent et de très exceptionnel. Je suis très honoré de cette expression de votre reconnaissance.

Mais la reconnaissance existe dans les deux sens. Pour moi, la reconnaissance qui $\mathrm{m}^{\prime}$ incombe doit être partagée. Mes réalisations bibliographiques - qui devaient plutôt être qualifiées d'aventures bibliographiques - ont été le résultat de collaborations. Par exemple, quand j'étais à l'Université de Calgary, j'ai eu le plaisir d'avoir pour collègue Apollonia Steele qui est ici ce soir. Le travail de l'Institut canadien des microreproductions historiques (ICMH) fut un point culminant bibliographique pour moi, non seulement en ce qui concerne la contribution que j'ai pu faire à l'érudition canadienne mais aussi parce $q u$ 'en se faisant je travaillais avec d'anciens 
récipiendaires de la médaille Tremaine comme Doug Lochhead et Bruce Peel - que je remercie tous les deux pour leur amitié et leur soutien. D'autres comme Basil Stuart-Stubbs et le regretté David Esplin ont droit à ma reconnaissance et à mes remerciements. Et il y eût bien entendu mes collègues de travail tel que mon successeur Bob Montague. Plus récemment, mes "aventures» m'ont amené à la compilation de la Bibliographie des bibliographies canadiennes $(B b c: 3)$. Pour cela je dois des remerciements à mon partenaire de recherches Gordon Adshead et à d'autres associé(e)s, dont Donna Brockmeyer-Klebaum qui est également ici ce soir. De plus, je voudrais remercier mon collègue et ami Merrill Distad.

En plus de ces personnes, je dois une reconnaissance toute particulière au personnel de la Bibliothèque nationale du Canada. Soit en ce qui concerne le travail de l'ICMH ou soit dans la préparation de $B b c: 3$, l'encouragement des administrateurs généraux de la Bibliothèque nationale, Guy Sylvestre et Marianne Scott, ainsi que de leur personnel, a été inestimable. Marianne ... je vous demanderais de transmettre ces remerciements à votre personnel.

Et, en terminant, $j^{\prime}$ aimerais remercier toutes les personnes qui ont travaillé aux arts bibliographiques et sans qui mon travail aurait été beaucoup, beaucoup plus difficile ou totalement impossible. La $B b c: 3$ est le fruit de leurs contributions.

Permettez-moi de clore avec une courte anecdote. Aujourd'hui on est assailli de tous côtés par des discussions sur la disparition du livre, sur les réductions des budgets de recherche, de développement des collections, et j'en passe. Dans un tel contexte, il est facile de sombrer dans le découragement. Quand je pense à tout cela, je me souviens de mon arrière-grand-père. Tout jeune adolescent, il traversa l'océan et travailla tout au long du périple qui le mena de New York jusqu'au nord du Manitoba où il s'établit. Encore adolescent, c'est là qu'il défricha sa terre, cultivant une partie de plus en plus étendue, et avec mon arrière-grand-mère éleva trois enfants. En faisant cela, comme d'autres dans des circonstances analogues, il créa un héritage qui est la nôtre aujourd'hui. Il accomplit cela, comme plusieurs de sa génération, sans les bienfaits d'une instruction - pourtant ils étaient savants. Nous avons plusieurs raisons d'être reconnaissants lorsque nous examinons nos réalisations mutuelles - et que nous nous inquiètons de notre situation. Notre défi est de travailler avec les ressources dont nous disposons et de nous souvenir de ceux et celles qui ont accomplit autant, sinon plus, avec beaucoup moins. Reconnaissons leur succès car ils ont bâti une nation. 